\title{
EKOWISATA DALAM MENJAGA SISTEM KETAHANAN LINGKUNGAN DESA ENDE
}

\author{
Fitria Pitri ${ }^{1}$, Samadi $^{1}$ \\ ${ }^{I}$ Pendidikan Kependudukan dan Lingkungan Hidup Pascasarjana Universitas Negeri Jakarta \\ Email: fitria.pitri92@gmail.com
}

\begin{abstract}
The village of Ende is a traditional hamlet located in Sengkol Village, Pujut Subdistrict, Central Lombok. These villagers live their daily activities by holding firmly to traditions that are still rooted from their ancestors. It is seen that the house thatched roofs that characterize the Sasak tribe would be an interesting scenery and become one of the attractions of tourists to come to the village. The purpose of this research is to know how effort done by sasak tribe in order to increase tourist attraction of Ende village and how social society role of society of Ende village to change its environment. This research uses qualitative descriptive method, through observation and interview. The results of this study indicate that the village of Ende as a tourist village has some efforts or ways that are done in order to improve the tourist attraction. The method used is inseparable from the rules and norms that apply in the village of Ende. This norm is of course based on local wisdom while maintaining the authenticity of their customs. In addition to the customary norms governing, there is also the social role of the Sasak people to preserve the culture and environment of Ende Village from the diffusion of foreign cultures.
\end{abstract}

Keywords: Travel Attractions, Local Wisdom, and Social Role 


\section{PENDAHULUAN}

Pulau Lombok adalah salah satu dari gugusan kepulauan Nusantara yang terletak di sebelah timur Pulau Bali dan sebelah barat Pulau Sumbawa. Di sebelah utara berbatasan dengan Laut Jawa dan Samudara Hindia di sebelah selatan. Di pulau ini terdapat tiga kabupaten yakni, Kabupaten Lombok Barat, Kabupaten Lombok Tengah, dan Kabupaten Lombok Timur, dan satu Kotamadya yaitu Kotamadya Mataram.

Kota Mataram merupakan ibukota Provinsi Nusa Tenggara Barat. Penduduk Pulau Lombok mayoritas Suku Sasak, di samping itu ada Suku mbojo (Bima), dompu, sumawa (Sumbawa), jawa, dan hindu. Lapangan pekerjaan utama masyarakat Lombok adalah petani, nelayan, kerajinan tangan, pertukangan, dan jual-beli. Meskipun Lombok sangat dipengaruhi oleh budaya Bali yang mayoritas memeluk agama Hindu Bali tetapi suku Sasak di Lombok mayoritas memeluk Islam. Uniknya pada sebagian kecil masyarakat suku Sasak, terdapat praktik agama Islam yang agak berbeda dengan Islam pada umumnya yakni Islam Wetu Telu, namun hanya berjumlah sekitar $1 \%$ yang melakukan praktek ibadah seperti itu. Ada pula sedikit warga suku Sasak yang menganut kepercayaan pra-
Islam yang disebut dengan nama "sasak Boda" (Erni, Budiwanti,. 2000).

Dari uraian latar belakang diatas, penulisan dalam makalah ini difokuskan pada salah satu desa saja yaitu desa Ende. Desa Ende merupakan dusun yang masih bersifat tradisional yang terletak di Desa Sengkol, Kecamatan Pujut, Lombok Tengah. Penduduk desa ini menjalani aktivitas sehari-hari dengan memegang teguh tradisi yang masih mengakar dari para leluhurnya. Hal ini terlihat rumah yang beratapkan alang-alang yang menjadi ciri Suku Sasak tentu menjadi pemandangan yang menarik.

Atap rumah yang dibuat miring memang disengaja agar para tamu yang mengunjungi rumah harus menundukkan kepala sebagai penghormatan kepada sang pemilik rumah. Selain itu rumah dibangun dengan menggunakan bahan tanah liat dicampur kotoran kerbau, kotoran ini jadi perekat atau bisa di bilang sebagai semen.

Terdapat berbagai tradisi yang unik di Desa Ende. Menurut Cannadine, tradisi adalah lembaga baru didandani dengan daya pikat kekunoan yang menentang zaman tetapi menjadi ciptaan mengagumkan. Tradisi lahir disaat tertentu ketika orang menetapkan fragmen tertentu dari warisan masa lalu sebagai tradisi. 
Tradisi berubah ketika orang memberikan perhatian khusus pada fragmen tradisi tertentu dan mengabaikan fragmen yang lain. Tradisi dapat bertahan dalam jangka waktu tertentu dan tradisi ini dapat hilang bila benda material dibuang dan gagasan ditolek atau dilupakan.

Tradisi lahir yaitu melalui dua cara. Cara pertama, tradisi muncul dari bawah melalui mekanisme kemunculan secara spontan dan tidak diharapkan serta melibatkan rakyat banyak. Karena sesuatu alasan, individu tertentu menemukan warisan historis yang menarik. Perhatian, ketakziman, kecintaan dan kekaguman yang kemudian disebarkan melalui berbagai cata, memengaruhi rakyat banyak. Sikap takzim dan kagum itu berubah menjadi perilaku dalam bentuk upacara, penelitiaan dan pemugaran peninggalan purbakala serta menafsir ulang keyakinan lama. Semua perbuatan itu memperkokoh sikap. Kekaguman dan tindakan individu menjadi milik bersama dan berubah menjadi fakta sosial sesungguhnya . Begitulah tradisi dilahirkan. Proses kelahiran tradisi sangat mirip dengan penyebaran temuan baru, hanya saja dalam kasus tradisi ini lebih berarti penemuan atau penemuan kembali yang telah ada di masa lalu ketimbang penciptaan sesuatu yang belum pernah ada sebelumnya.
Cara kedua, tradisi muncul dari atas melalui mekanisme paksaan. Sesuatu yang dianggap sebagai tradisi dipilih dan dijadikan perhatian umum atau dipaksakan oleh individu yang berpengaruh atau berkuasa. Raja mungkin memaksakan tradisi dinastinya kepada rakyatnya. Diktator menarik perhatian rakyatnya kepada kejayaan bangsanya di masa lalu. Perancang mode terkenal menemukan inspirasi dari masa lalu dan mendiktekan gaya "kuno" kepada konsumen.

Tradisi unik yang dimiliki Suku Sasak, yaitu kawin lari. Dalam tradisi ini, pihak pria membawa lari wanita yang disukainya. Ini dilakukan tanpa diketahui oleh orangtua si wanita. Pelarian yang dilakukan biasanya berlangsung selama 3 hari. Setelah itu, orangtua wanita akan menebus untuk membicarakan kelanjutan hubungan ke jenjang yang lebih serius.

Pernikahan di Desa Ende biasanya dilakukan di seputar lingkungan desa. Perkawinan antarsepupu atau saudara masih sering terjadi. Jika ada seseorang yang ingin menikah dengan pihak luar dusun, orang tersebut diharuskan membayar denda yang nilainya cukup besar untuk kalangan masyarakat dusun (Nur,Alam MN r. 2013). 
Hal tersebut menjadi salah satu daya tarik para wisatawan untuk mengunjungi desa tersebut. Oleh karena itu, penulis ingin membahas tentang bagaimana upaya yang dilakukan suku sasak dalam rangka meningkatkan daya tarik wisata desa ende serta bagaimana peran sosial budaya masyarakat desa ende terhadap perubahan lingkungannya.

Destinasi Pariwisata adalah area atau kawasan geografis yang berbeda dalam suatu atau lebih wilayah administratif yang di dalamnya terdapat unsur daya tarik wisata, fasilitas pariwisata, aksesibilitas, masyarakat serta wisatawan yang saling terkait dan melengkapi untuk terwujudnya kegiatan kepariwisataan. Daya tarik yang tidak atau belum dikembangankan merupakan sumber daya potensial dan belum dapat disebut daya tarik wisata, sampai adanya suatu jenis pengembangan tertentu.

Objek dan daya tarik wisata merupakan dasar bagi kepariwisataan. Tanpa adanya daya tarik di suatu daerah atau tempat tertentu kepariwisataan sulit untuk dikembangkan. Daya Tarik Wisata sejatinya merupakan kata lain dari obyek wisata namun sesuai peraturan pemerintah Indonesia tahun 2009 kata obyek wisata sudah tidak relevan lagi untuk menyebutkan suatu daerah tujuan wisatawan maka digunakanlah kata " Daya Tarik Wisata".

Kearifan lokal dalam bahasa asing sering dikonsepsikan sebagai kebijakan setempat (local wisdom), pengetahuan setempat (local knowledge) atau kecerdasan setempat (local genious). Kearifan lokal juga dapat dimaknai sebuah pemikiran tentang hidup. Pemikiran tersebut dilandasi nalar jernih, budi yang baik, dan memuat hal-hal positif. Kearifan lokal seperti ini dapat dieksplorasi dengan menelusuri proses pembelajaran satu generasi ke generasi berikutnya (Mungmachon, 2012).

Studi di Thailand menunjukkan bahwa masyarakat setempat dengan kearifan lokalnya mampu melindungi lingkungan (Chaipar, 2003). Kearifan lokal tidak hanya terdapat dalam sastra tradisional (sastra lisan atau sastra tulis) namun juga terdapat dalam berbagai bidang kehidupan nyata seperti filosofi, pandangan hidup dan arsitektur (Asry, 2010). Kearifan lokal dapat diterjemahkan sebagai karya akal budi, perasaan mendalam, tabiat, bentuk perangai, dan anjuran untuk kemuliaan manusia. Penguasaan atas kearifan lokal akan mengusung jiwa mereka semakin berbudi luhur.

\section{METODOLOGI}


Dalam penelitian ini penelitian menggunakan penelitian kualitatif dengan menggunakan pendekatan fenomenologi. Dalam buku Reseach Design: Kuantitatif, Kualitatif dan Mixed. Cresswell menyatakan bahwa "penelitian kualitatif dipilih dalam rangka memperoleh data yang lebih mendalam dengan melihat persepsi-persepsi dan pengalamanpengalaman mereka terhadap suatu program, peristiwa, aktivitas, proses atau sekolompok individu" (John W. Creswell, 2010).

Denzin dan Lincoln (1987) dan Moleong (2010) menegaskan bahwa penelitian kualitatif menggunakan latar ilmiah yang bertujuan untuk menafsirkan fenomena yang terjadi dan dilakukan dengan menggunakan berbagai macam metode seperti wawancara, pengamatan, dan pemanfaatan dokumen. Pengambilan informasi dilalukan pada responden kunci dan para pengelola pihak wisata.

Penelitian dilakukan pada tanggal 26 April 2017 di Desa Ende, Lombok Tengah. Informan atau responden dalam penelitian ini adalah pihak pengelola dan pemandu wisata Desa Ende.

Dalam penelitian kualitatif dengan pendekatan fenomenologi penentuan jumlah partisipan dapat ditentukan berdasarkan pendapat dari Creswell
(1998), dimana ukuran sampel yang digunakan adalah 5-25 orang. Beberapa peneliti menyarankan untuk mementingkan tercapainya titik jenuh (Poerwandari, 2009). Pada penelitian ini menggunakan partisipan sebanyak 7 orang. Jumlah partisipan ditentukan karena data yang peneliti dapatkan telah mencapai saturasi pada partisipan ke7.

Teknik pengumpulan data dilakukan dengan melakukan kegiatan wawancara yang mendalam untuk menggali informasi. Proses wawancara dilakukan secara informal. Bentuk pertanyaan yang digunakan adalah jenis pertanyaan terbuka agar para responden dapat menceritakan secara leluasa.

Partisipan dalam penelitian ini adalah pihak pengelola dan pemandu wisata yang bekerja sebagai pemandu wisata di Desa Ende yang terdiri dari 7 orang partisipan.

Table 1

Matriks Responden

\begin{tabular}{|l|l|l|}
\hline \multicolumn{1}{|c|}{$\begin{array}{c}\text { Nama } \\
\text { Responden }\end{array}$} & $\begin{array}{c}\text { Status } \\
\text { Responden }\end{array}$ & $\begin{array}{c}\text { Status } \\
\text { dalam } \\
\text { Penilitian }\end{array}$ \\
\hline Bapak & Pengelola & Informan \\
Temu & Wisata & Kunci \\
& Desa Ende & \\
\hline
\end{tabular}




\begin{tabular}{|c|c|c|}
\hline $\begin{array}{l}\text { Bapak } \\
\text { Kadir }\end{array}$ & $\begin{array}{l}\text { Tour Guide } \\
\text { Desa Ende }\end{array}$ & $\begin{array}{l}\text { Informan } \\
\text { Utama }\end{array}$ \\
\hline $\begin{array}{l}\text { Bapak } \\
\text { Hayudin }\end{array}$ & $\begin{array}{l}\text { Tour Guide } \\
\text { Desa Ende }\end{array}$ & $\begin{array}{l}\text { Informan } \\
\text { Utama }\end{array}$ \\
\hline Bapak Akip & $\begin{array}{l}\text { Tour Guide } \\
\text { Desa Ende }\end{array}$ & $\begin{array}{l}\text { Informan } \\
\text { Utama }\end{array}$ \\
\hline $\begin{array}{l}\text { Bapak } \\
\text { Indro }\end{array}$ & $\begin{array}{l}\text { Tour Guide } \\
\text { Desa Ende }\end{array}$ & $\begin{array}{l}\text { Informan } \\
\text { Utama }\end{array}$ \\
\hline $\begin{array}{l}\text { Bapak } \\
\text { Loleh }\end{array}$ & $\begin{array}{l}\text { Tour Guide } \\
\text { Desa Ende }\end{array}$ & $\begin{array}{l}\text { Informan } \\
\text { Utama }\end{array}$ \\
\hline $\begin{array}{l}\text { Bapak } \\
\text { Andra }\end{array}$ & $\begin{array}{l}\text { Tour Guide } \\
\text { Desa Ende }\end{array}$ & $\begin{array}{l}\text { Informan } \\
\text { Utama }\end{array}$ \\
\hline
\end{tabular}

Sumber: Hasil Rumusan Peneliti, 2017

\section{HASIL DAN PEMBAHASAN}

Desa Ende adalah salah satu desa wisata yang terletak di Lombok Tengah. Setiap harinya Desa Ende dikunjungi oleh banyak wisatawan. Wisatawan yang berkunjung ke Desa Ende per harinya bisa mencapai ratusan orang. Hal itu terlihat dari banyaknya rombongan wisatawan yang hadir dengan menggunakan mobil bus dan mobil pribadi. Bisa dibayangkan jumlah perharinya saja sudah ratusan wisatawan, bagaimana bila sebulan mungkin bisa ribuan pengunjung yang datang ke Desa Ende.

Wisatawan yang berkunjung pun tidak hanya kalangan umum tetapi pelajar pun sering berkunjung dan melakukan penelitian terhadap masyarakat Suku Sasak yang berada di Desa Ende. Para pelajar biasanya sampai menginap di rumah-rumah warga beberapa hari untuk melakukan penelitian. Rumah warga yang digunakan untuk menginap biasaya dipersiapkan dan dikosongkan terlebih dahulu oleh para pemilik rumah. Pemilik rumah untuk sementara menumpang menginap dirumah kerabat terdekat untuk beberapa hari selama rumahnya digukan untuk para wisatawan. Tetapi tidak semua seperti itu, terkadang terdapat wisatawan yang menginap dirumah warga bersamasama. Dimana biasanya pemilik rumah mengalah untuk tidur di bagian depan rumah.

Dengan banyaknya wisatawan yang datang ke Desa Ende, maka akan meningkatkan penghasilan atau devisa bagi Desa Ende. Untuk masuk kedalam Desa tersebut cukup dengan memberika uang seikhlasnya kebagian pengelola keuangan desa tersebut dan mengisi buku tamu di pos depan sebelum memasuki desa.

Hasil uang tersebut biasanya akan di bagikan kepada para warga secara merata dalam bentuk sembako, seperti beras, minyak dan gula. Selain itu, di bukanya Desa Ende sebagai desa wisata maka dapat memabawa dampak yang postif bagi para warga sekitar. Hal itu dikarena muncul lapangan pekerjaan. Banyak para pemuda- 
pemuda desa menjadi tour gaide untuk menemani wisatawan untuk berkeliling dan menjeaskan tentang Desa Ende.

Suasana di Desa Ende tidak begitu ramai seperti Desa Sade. Hal ini terlihat dari jumlah kepala keluarga yang ada di desa tersebut. Hanya terdapat 30 kepala keluarga yang terdapat di Desa Sade. Selain itu, rumah adat pun tidak terlalu banyak dan masih terdapat lahan kosong yag luas di belakang rumah.

Ditambah dengan masih banyaknya warga yang tidak bisa berbahasa Indonesia. Hal seperti itu terkadang yang mempersulit kami untuk berinteraksi dengan warga Suku Sasak.

Oleh karena itu, pihak pengelola Desa Ende sedang meningkatkan usaha mempromosikan desanya sebagai desa wisata kepada para pengunjung. Untuk meningkatkan daya tarik wisatawan, maka diperlukan pengembangan usaha seperti dibuatnya sebuah galeri atau koperasi penjualan kain tenun hasil pembuatan para warga khusunya ibu-ibu Suku Sasak. Biasanya mereka menjual kain tenunan ketika sudah habis masa panen. Hal demikian dilakukan untuk tetap mendapatkan uang dimasa paceklik.

Desa Ende adalah desa wisata, sebagai desa wisata tentunya banyak hal yang harus diperhatikan untuk menunjang daya tarik desa tersebut. Salah satu yang harus diperhatikan adalah fasilitas yang ada di sana. Wisatawan atau pengunjung memiliki hak untuk menikmati fasilitas yang ada.

Oleh karena itu, fasilitas tersebut harus selalu diberikan perawatan dan dijaga kebersihannya. Fasilitas-fasilitas disini bisa berupa kamar kecil (WC), tempat berteduh bila terjadi hujan dan tempat pembuangan sampah.

Di Desa Ende sendiri ternyata tidak ada perawatan khusus untuk merawat fasilitas yang ada, serta tidak adanya petugas yang khusus merawat objek wisata yang ada. Hal itu dikarenakan objek yang ada disana adalah tanggung jawab para warga

Suku Sasak sendiri. Jika mengingankan lingkungan bersih dan nyaman, maka mereka harus mejaga kebersihan desa dengan inisiatif sendiri. Kesadaran para wargalah yang menjadi kepercayaan untuk menjaga kebersihan lingkungan.

Pengembangan infrastruktur pun tidak terlihat pada Desa Sade, di sana masih tetap mempertahankan kondisi lingkungan seperti bentuk rumah yang menjadi ciri khas desa tersebut. Serta tidak terdapat kebijakan-kebijakan khusus yanga ada di 
desa tersebut. Terdapat hukum adat saja yang berlaku untuk warga Suku Sasak dan tidak berlaku untuk wisatawan.

Jika melihat kondisi Desa Sade sekarang, maka perlu ada pengembangan infrastruktur yang cukup baik untuk meningkatkan daya tarik wisatawan untuk datang ke Desa Ende.

Peraturan Desa adalah peraturan perundang-undangan yang ditetapkan oleh Kepala Desa bersama Badan Permusyawaratan Desa. Peraturan ini berlaku di wilayah desa tertentu. Peraturan Desa merupakan penjabaran lebih lanjut dari peraturan perundangundangan yang lebih tinggi dengan memperhatikan kondisi sosial budaya masyarakat desa setempat.

Peraturan Desa dilarang bertentangan dengan kepentingan umum dan/atau peraturan perundang-undangan yang lebih tinggi. Masyarakat berhak memberikan masukan secara lisan atau tertulis dalam rangka penyiapan atau pembahasan Rancangan Peraturan Desa.

\section{Manfaat Peraturan Desa}

1. Sebagai pedoman kerja bagi semua pihak dalam penyelenggaraan kegiatan di desa
2. Terciptanya tatanan kehidupan yang serasi, selaras dan seimbang di desa

3. Memudahkan pencapaian tujuan

4. Sebagai acuan dalam rangka pengendalian dan pengawasan

5. Sebagai dasar pengenaan sanksi atau hukuman

6. Mengurangi kemungkinan terjadinya penyimpangan atau kesalahan

\section{JENIS-JENIS PERATURAN DESA}

Jenis dan ragam Peraturan Desa yang disusun dan ditetapkan bergantung pada kebutuhan penyelenggara pemerintahan di desa. Untuk itu diharapkan kepada Pemerintah Desa dan BPD agar dapat mengidentifikasi topik-topik yang perlu dibuat sebagai Peraturan Desa. Tingkat kepentingan ini hendaknya dilihat dalam kerangka kepentingan sebagian besar masyarakat agar Peraturan Desa yang dibuat benar-benar aspiratif.

Peraturan Desa juga perlu dibuat karena adanya perintah atau keharusan yang ditetapkan melalui peraturan yang lebih tinggi. Peraturan Desa seperti ini biasanya merupakan penjabaran dan pengukuhan dari peraturan yang lebih tinggi tersebut.

Meskipun Desa Ende tidak memiliki regulasi hukum yang pasti, namun masih terdapat norma-norma yang berbasis kearifan lokal desa setempat. Norma- 
norma yang berbasis kearifan lokal Desa Ende salaha satunya ialah bentuk rumah yang beratapkan alang-alang yang menjadi ciri Suku Sasak dan tentu menjadi pemandangan yang menarik. Atap rumah yang dibuat miring memang disengaja agar para tamu yang mengunjungi rumah harus menundukkan kepala sebagai penghormatan kepada sang pemilik rumah. Selain itu rumah dibangun dengan menggunakan bahan tanah liat dicampur kotoran kerbau, kotoran ini jadi perekat atau bisa di bilang sebagai semen. Hal ini dilakukan untuk tetap menjaga kearifan lokal desa tersebut.

Masyarakat Suku Sasak yang tinggal di Desa Ende sangat mempertahankan adat istiadat dan sistem norma dalam kehidupan kesehariannya. Masing-masing dusun atau desa mempunyai awiq-awiq dusun (aturan dusun atau desa) yang ditetapkan oleh para tokoh agama dan tokoh masyarakat dan bagi mereka yang melanggar akan dikenakan sanksi sesuai kesepakatan. Adat istiadat yang berlaku di sana dapat terlihat dari kondisi lahan serta bangunan rumah yang mereka buat.

Di Desa Ende jumlah rumah tidak terlalu banyak. Jumlah rumah masih dapat dihitung dengan mudah, mengingat letak rumah pun tidak terlalu dekat satu rumah dengan rumah yang lainnya (antar rumah).
Jika dilihat dari jumlah kepala keluarga yang hanya 30 orang, maka dapat dibayangkan jumlah rumah yang ada di sana. Ditambah lagi dengan dibuatnya peraturan adat yang menyatakan, jika sudah berkeluarga dan ingin membuat rumah, maka rumah dibuat harus mirip dengan rumah orang tuanya. Jika tidak ingin, maka mereka harus keluar dari desa tersebut untuk membuat rumah yang diinginkan. Mungkin itu salah satu faktor rumah di Desa Enda terlihat sedikit.

Dari jumlah rumah yang sedikit tersebut terlihat pula lahan kosong yang sangat luas dibelakang rumah warga. Lahan kosong tersebut terlihat seperti kebun yang dibiarkan oleh warga sekitar. Peraturan ada seperti itu yang membawa dampak yang baik bagi lingkungan dan peran masyarakat sekitar pula lah yang sangat diutamakan karena mereka telah patuh terhadap peraturan yang berlaku dan tetap menjaga keasrian tempat tinggal mereka, tanpa harus merusaknya.

Selain itu jika dilihat dari bentuk rumah yang dibangun pun sangat menjaga kearifan lingkungan. Semua rumah di Desa Ende dibangun dengan menggunakan bahan tanah liat dicampur kotoran kerbau untuk bagian tembok dan lantai rumah, kotoran ini jadi perekat atau bisa di bilang sebagai semen. Penggunaan kotoran 
kerbau dilakukan setiap bulan sekali. Hal ini lakukan untuk tetap menjaga kekuatan tembok dan lantai rumah.

Selain itu, mereka percaya bahwa kotoran kerbau dapat membawa keberkahan bagi mereka. Tidak hanya itu saja, jika diperhatikan setiap rumah atapnya terbuat dari jerami yang disusun sedemikian rupa agar kuat dan tahan adri terjangan angin, hujan dan panas. Serta jendela di semua remuah terbuat dari bambu dan kayu, tidak ada yang terbuat dari kaca. Dari semua itu membawa dampak yang baik, yaitu dapat mengurangi pemanasan global akaibat dari efek rumah kaca. Begitulah cara masyarakat Suku Sasak menjaga kearifan lokal Desa Ende.

\section{KESIMPULAN}

Sebagai desa wisata Desa Ende memiliki beberapa upaya atau cara yang dilakukan dalam rangka meningkatkan daya tarik wisata. Cara yang digunakan pun tak terlepas dari aturan serta norma-norma yang berlaku di Desa Ende. Norma-norma tersebut tentunya berbasis kearifan lokal dengan tetap menjaga keaslian adat mereka. Selain terdapat norma adat yang mengatur, terdapat juga peran sosial masyarakat Suku Sasak untuk tetap menjaga budaya serta lingkungan Desa Ende dari difusi budaya asing.

\section{DAFTAR PUSTAKA}

Alam MN,Nur. 2013. "Sade Desa Asli Suku Sasak". Tersedia Pada https://alanmn.wordpress.com. (Diakses tanggal 3 Mei 2017).

Bruce.S Jansson. 1994. Social Policy, from theory to policy practice, second edition. Brooks / Cole Publishing Company. California.

Budiwanti, Erni. 2000. Islam Sasak: Wetu Telu Versus Waktu Lima. Yogyakarta: PT LKiS Pelangi Aksara

Hamzuri. 2000. Warisan Tradisional Itu Indahdan Unik. Jakarta: PT Raja Grafindo Persada

James Midgley, etc. The Handbook of Social Policy National Association of Social Worker. Encyclopedia Of Social Work, Vol II.

Sartini. 2004. Menggali kearifan lokal nusantara sebuah kajian filsafati. Dalam: Jurnal Filsafat. 